\title{
Medium optimization of $\beta$-glucanase production by Bacillus subtilis SAHA 32.6 used as biological control of oil palm pathogen
}

\author{
Rike Tri Kumala Dewi ${ }^{1}$, Nisa Rachmania Mubarik ${ }^{2}$, Maggy Thenawijaya Suhartono ${ }^{3}$ \\ ${ }^{1}$ Study Program of Biotechnology, Postgraduate School, Bogor Agricultural University, Bogor, Indonesia; '2Department of Biology, Faculty of \\ Mathematics and Natural Sciences, Bogor Agricultural University, Bogor, Indonesia; ${ }^{3}$ Department of Food Science and Technology, Faculty of \\ Agricultural Technology, Bogor Agricultural University, Bogor, Indonesia
}

\section{A B S T R A C T}

Beta-glucanase enzyme can degrade $\beta$-glucan polysaccharide to saccharide oligomers and glucose monomers. The enzyme can be used as biological control to degrade $\beta$-glucan in cell wall of fungal pathogens. The objective of this study was to determine the optimum medium for bacterial $\beta$-glucanase production and to use the enzyme as biological control of oil palm pathogenic fungi. Medium optimization were carried out using Response Surface Methodology (RSM) with 18 experimental run of Central Composite Design (CCD) on three variables (oat $\beta$-glucan, yeast extract, and bacterial inoculum). The results showed that $\beta$-glucanase produced by Bacillus subtilis SAHA 32.6 was strongly influenced by bacterial inoculum size than oat $\beta$-glucan and yeast extract concentration. Beta-glucanase of optimized medium could inhibit the growth of oil palm pathogenic fungi, i.e Curvularia affinis and Colletotrichum gloeosporioides. The ammonium sulphate fractionation of the $\beta$-glucanase could inhibit the fungi better than crude enzyme. The bacterial $\beta$-glucanase of $B$. subtilis SAHA 32.6 can be used as bio-fungicide to attack of pathogenic fungi in the oil palm nursery.

Keywords: Bacterial inoculum; $\beta$-glucanase; Pathogenic fungi; Response surface methodology

\section{INTRODUCTION}

Beta-glucanase is a hydrolytic enzyme which can degrade $\beta$-glucan polysaccharide substrate to glucose monomer or saccharide oligomer (Pitson et al., 1993). An application of this enzyme can be used as biological control of fungal pathogen for its ability to hydrolyze $\beta$-glucan. Beta-glucan is a second major polysaccharide in fungal pathogen cell wall after chitin (Pitson et al., 1993) and found in almost all fungal cell wall except Oomycetes which contain cellulose (Lorraque et al., 2012).

Curvularia affinis and Colletotrichum gloeosporioides are fungal pathogens which widely attacks on the leaves of oil palm (Elaeis guinensis Jacq.) nursery. Infection by this fungus can reach up to $38 \%$ (Solehudin et al., 2012). This disease is very harmful because it can prolong lifespan breeding and the period of immature plant (Solehudin et al, 2012). So, infection of these fungus can decrease oil palm economic value. Leaf blight disease was first reported in Indonesia in the 1920s and has spread massively to all region of the country (Suwandi et al., 2012). In addition, this disease was reported has spread in Thailand (Kittimorakul et al., 2013), and India (Gautam, 2014).

Some bacteria have been known as $\beta$-glucanase producer, such as, Bacillus clausii (Aono et al., 1995), B. subtilis (Manjula and Podile, 2005; Tang et al., 2004; Leelasuphakul et al., 2006; Narasimhan et al., 2013), B. circulans (Aono et al., 1995), B. halodurans (Akita et al., 2005), B. licheniformis (Chaari et al., 2012), Arthrobactersp. (Pang et al., 2004), and Pseudomonas cepacia (Fridlender et al., 1993). Beta-glucanase produced by bacteria could inhibit fungal pathogens growth (Aono et al., 1995; Manjula and Podile, 2005; Leelasuphakul et al., 2006). B. subtilis and Pseudomonas are usually used for a biological control of fungal pathogen growth (Saharan and Nehra, 2011).

\footnotetext{
*Corresponding author:

Nisa Rachmania Mubarik, Department of Biology, Faculty of Mathematics and Natural Sciences, Bogor Agricultural University, Bogor, 16628. Indonesia. E-mail: nrachmania@ipb.ac.id
} 
Productivity of bacterial $\beta$-glucanase enzyme was influenced by inducer and nutrition sources (Tang et al., 2004; Khare and Upadhyay, 2011), bacterial inoculums size (He et al., 2003), and physical conditions, such as $\mathrm{pH}$, aeration, and temperature. Optimization conditions are needed to increase $\beta$-glucanase production, but it was difficult to optimize the cultural conditions with common method by using several of batch cultures. It will long-time consumption, need a high cost, could not see interaction between variables and could not reach the true optimum value (He et al., 2003).

Response Surface Methodology (RSM) is a model of mathematical and statistical technique in development, improvement, and optimization of multiple variables to determine maximum response (Myers and Montgomery, 2002). The method can be used to evaluate the effect of each variable on the response. In the recent works, RSM has been applied to optimize conditions in enhancement of enzyme production for biomedicine, food, feed, and bioenergy industry (He et al., 2003; Tang et al., 2004; Patel et al., 2011; Jabasingh and Nachiyar et al., 2012; Kahar et al., 2014). Narasimhan et al. (2013) has optimized conditions of $\beta$-glucanase production for biological control agents, but only used the common approach (one-factor at a time). The research of medium optimization of $\beta$-glucanase production using RSM for biological control agents has not been reported.

The objective of the research was to determine the optimum medium of $\beta$-glucanase production by selected of biological control bacteria by using RSM. The evaluated variables were concentration of $\beta$-glucan as inducer, yeast extract as nutrition source, and size of bacterial inoculum. Furthermore, fractionation of $\beta$-glucanase by ammonium sulphate was carried out to determine the effectiveness of $\beta$-glucanase in inhibiting the pathogenic fungi.

\section{MATERIALS AND METHODS}

\section{Microorganism and cultures maintenance}

Eight bacterial isolates (SAHA 12.17, SAHA 3.5, SAHA 32.6, SAHN 13.26, SAHA 2.2, SAHA 2.1, SAHA 3.4) were isolated from oil palm plantation soil in Jambi Province, Indonesia, and fungal pathogens (Curvularia affinis and Colletotrichum gloeosporioides) were obtained from IPBCC (Institut Pertanian Bogor Culture Collection), Bogor Agricultural University, Bogor, Indonesia. Bacterial cultures were maintained on a Nutrient Agar (Difco) containing $1 \% \beta$-glucan for $24 \mathrm{~h}$ at $37^{\circ} \mathrm{C}$ and stored at $4{ }^{\circ} \mathrm{C}$. Betaglucan was extracted from oat bran based on Beer et al. (1996) method by using an alkaline solution of $20 \%$ $\mathrm{Na}_{2} \mathrm{CO}_{3}$. Fungal pathogens were maintained on Potato Dextrose Agar (HiMedia) at room temperature.

\section{Screening of $\beta$-glucanase produced by bacteria}

All bacterial isolates were tested for their glucanolytic activity using $\beta$-glucan agar by conventional plate method. Initial detection of $\beta$-glucanase was assayed by congored staining (Teather and Wood, 1982). A clear zone of $\beta$-glucan hydrolysis around the bacterial colony showed an indication of $\beta$-glucanase production by bacteria. Glucanolytic index was calculated using the equation: $(\mathrm{A}-\mathrm{B}) \mathrm{B}^{-1}$, where $\mathrm{A}$ is diameter of the clear zone, and $\mathrm{B}$ is diameter of bacterial colonies.

The ability of isolates to inhibit the growth of fungal pathogens C. gloeosporioides and C. affinis were tested by Fokkema (1973) method. Each fungal inoculum ( $\pm 20 \mathrm{~mm}$ ) was placed opposite each other at a distance of fungal pathogen at least $3 \mathrm{~cm}$ on Potato Dextrose Agar (PDA) medium. The culture were incubated for 7 days at $27^{\circ} \mathrm{C}$. The inhibition of fungal pathogens growth by bacteria were calculated with the equation $=\left(\mathrm{R}_{1}-\mathrm{R}_{2}\right) \mathrm{R}_{1}^{-1} \times 100 \%$, where $R_{1}$ is length of radial growth towards plate edge and $\mathrm{R}_{2}$ is length of radial growth towards bacteria. The best bacterial ability was selected for further works.

\section{Identification of selected bacterial isolates}

Selected bacterial isolate was identified based on Gram staining and 16S rRNA amplification. Isolation of total DNA was done following procedures of Presto ${ }^{\mathrm{TM}}$ Mini gDNA Bacteria Kit (Geneaid Biotech Ltd, Japan). Total DNA used as a template was amplified by Polymerase Chain Reaction (PCR) machine. Template was mixed with GoTaq Green Master Mix 2 (Promega, Madison, WI, USA), nuclease water, and two universal bacterial specific primers $63 \mathrm{~F}$ (5'-CAGGCCCACAGGTAACAAGTC) and 1387r (5'-GGGCAAGGCCGGGTAWGT) (Marchesi et al. 1998) with condition of denaturation $\left(95^{\circ} \mathrm{C}, 1 \mathrm{~min}\right)$, annealing $\left(55^{\circ} \mathrm{C}, 1 \mathrm{~min}\right)$, elongation $\left(72^{\circ} \mathrm{C}, 1.5 \mathrm{~min}\right)$, and extension $\left(72^{\circ} \mathrm{C}, 10 \mathrm{~min}\right)$ for 30 cycles. PCR products was sequenced at $1^{\text {st }} \mathrm{BASE}$ laboratories, Malaysia. The obtained sequence was compare with the GeneBank database of National Center for Biotechnology Information (NCBI) using BLAST-N program then phylogenetic tree was constructed by MEGA (Molecular Evolutionary Genetics Analysis) version 6.0 software (MegaSoftware, Inc., Tempe, Arizona, USA) using neighbour-joining method with 1000 replication of bootstrap.

\section{Determination of selected bacterial growth curve and $\beta$-glucanase production}

Inoculum was prepared in $50 \mathrm{ml}$ media containing (\%): $\mathrm{K}_{2} \mathrm{HPO}_{4}(0.065), \mathrm{KH}_{2} \mathrm{PO}_{4}(0.25),\left(\mathrm{NH}_{4}\right)_{2} \mathrm{SO}_{4}(0.05)$, $\mathrm{NaCl}(0.25), \mathrm{MgSO}_{4} 7 \mathrm{H}_{2} \mathrm{O}(0.012)$, yeast extract $(0.15)$ supplemented with $1 \% \beta$-glucan, incubated on shaker incubator (311DS Environmental Shaking Incubator, Labnet International. Inc, North America) at $37{ }^{\circ} \mathrm{C}$ 
and $130 \mathrm{rpm}$ agitation until the optical density achieved $10^{8} \mathrm{CFU} \mathrm{ml}{ }^{-1}$. Furthermore, $1 \%$ inoculum were cultivated into $250 \mathrm{ml}$ erlenmeyer flask containing $100 \mathrm{ml}$ production media supplemented with $1 \% \beta$-glucan at $\mathrm{pH} 7$. The culture was collected every $3 \mathrm{~h}$ until $24 \mathrm{~h}$ for the measure of optical density at wavelength of $580 \mathrm{~nm}$. The culture was then centrifuged at $6708 \mathrm{xg}$ (centrifuge Eppendorf MiniSpin with rotor F-45-12-11) for 15 min to obtain crude extract of $\beta$-glucanase enzyme. The crude of $\beta$-glucanase was then measured for its activity. The showing highest $\beta$-glucanase activity was used for optimization in cultivation process using RSM.

\section{Assay of $\beta$-glucanase activity}

Beta-glucanase activity was determined by measuring the reducing sugar released from $\beta$-glucan as a substrate using DNS (dinitrosalicylic acid) method (Miller, 1959). Crude extract $(500 \mu \mathrm{l})$ was incubated at $37^{\circ} \mathrm{C}$ for $30 \mathrm{~min}$ with $3 \% \beta$-glucan substrate $(500 \mu \mathrm{l})$ which dissolved in $50 \mathrm{mM}$ $\mathrm{pH} 7$ phosphate buffer. Then it followed by heating for $15 \mathrm{~min}$ in boiling water. The absorbance was measured at a wavelength of $540 \mathrm{~nm}$. The amount of reducing sugar released was calculated using a glucose as standard. One unit of $\beta$-glucanase activity is defined as the amount of enzyme required to produce $1 \mu \mathrm{mol}$ of glucose in $1 \mathrm{~min}$ incubation. Protein concentration was determined by micro-assay of Bradford (1976) using bovine serum albumin as standard. Specific activity of enzyme was performed by comparison of $\beta$-glucanase enzyme activity with a protein concentration.

\section{Experimental design and optimization by RSM}

RSM was used to optimize the medium for the production of $\beta$-glucanase by selected bacteria. There were three variables used for optimization i.e. concentration of oat $\beta$-glucan $\left(X_{1}\right)$, concentration of yeast extract $\left(X_{2}\right)$, and size of inoculum $\left(\mathrm{X}_{3}\right)$. Each variables in the CCD was studied at five levels with coded level $-2,-1,0,+1,+2$ (Table 1). A factorial CCD with six axial points and four replications at the centre points leading to a total of eighteen experimental running (Table 3). The cultivation variables conditions were varied according to CCD design. The experiments were conducted in $250 \mathrm{ml}$ erlenmeyer flask containing production media of $\mathrm{pH} 7$. The culture flasks were incubated on shakker incubator at $37^{\circ} \mathrm{C}$ and $130 \mathrm{rpm}$ agitation. After cultivation, the contents of each flask was centrifuged at $6708 \mathrm{xg}$ (centrifuge Eppendorf MiniSpin with rotor F-45-12-11) for $15 \mathrm{~min}$ and the supernatant was then measured for its $\beta$-glucanase specific activity.

The relationship between the response and independent variables are explained by using second order polynomial following equation:

$$
\mathrm{Y}=\beta_{0}+\sum \beta_{\mathrm{i}} \mathrm{x}_{\mathrm{i}}+\sum \beta_{\mathrm{ij}} \mathrm{x}_{\mathrm{i}} \mathrm{x}_{\mathrm{j}}+\sum \beta_{\mathrm{ii}} \mathrm{x}_{\mathrm{i}}^{2}
$$

Table 1: Variables and coded value of CCD

\begin{tabular}{lllccccc}
\hline $\begin{array}{llcc}\text { Coded } \\
\text { variables }\end{array}$ & Variables & Unit & \multicolumn{5}{c}{ Coded value } \\
\cline { 3 - 7 } & & & $\mathbf{- 2}$ & $-\mathbf{1}$ & $\mathbf{0}$ & $\boldsymbol{+ 1}$ & $\boldsymbol{+ 2}$ \\
\hline $\mathrm{X}_{1}$ & $\beta$-glucan oat & $\%(\mathrm{w} / \mathrm{v})$ & 1 & 2 & 3 & 4 & 5 \\
$\mathrm{X}_{2}$ & Yeast extract & $\%(\mathrm{w} / \mathrm{v})$ & 0.1 & 0.2 & 0.3 & 0.4 & 0.5 \\
$\mathrm{X}_{3}$ & Bacterial inoculum & $\%(\mathrm{w} / \mathrm{v})$ & 1 & 2 & 3 & 4 & 5 \\
\hline
\end{tabular}

Table 2: The screening of bacterial glucanolytic activity and bacterial ability in inhibit the growth of pathogenic fungi

\begin{tabular}{lccc}
\hline Bacteria & $\begin{array}{c}\text { Index of } \\
\text { glucanolytic }\end{array}$ & $\begin{array}{c}\text { The growth of fungal pathogens } \\
\text { inhibition (\%) }\end{array}$ \\
\cline { 3 - 4 } & & C. gloeosporioides & C. affinis \\
\hline SAHA 12.17 & $1.17 \pm 0.19$ & $44.45 \pm 0.00$ & 0 \\
SAHA 3.5 & $2.64 \pm 0.00$ & 0 & $75.00 \pm 0.00$ \\
SAHA 32.6 & $6.50 \pm 0.26$ & $82.79 \pm 0.26$ & $60.60 \pm 8.57$ \\
\hline
\end{tabular}

Table 3: Central composite design matrix

\begin{tabular}{lccclcc}
\hline Run & $\mathbf{X}_{1}$ & $\mathbf{X}_{2}$ & $\mathbf{X}_{3}$ & Design type & Actual Y & Predicted Y \\
\hline 1 & -1 & -1 & -1 & Factorial & 0.111 & 0.092 \\
2 & +1 & -1 & -1 & Factorial & 0.087 & 0.068 \\
3 & -1 & +1 & -1 & Factorial & 0.109 & 0.117 \\
4 & +1 & +1 & -1 & Factorial & 0.083 & 0.084 \\
5 & -1 & -1 & +1 & Factorial & 0.159 & 0.194 \\
6 & +1 & -1 & +1 & Factorial & 0.209 & 0.208 \\
7 & -1 & +1 & +1 & Factorial & 0.081 & 0.108 \\
8 & +1 & +1 & +1 & Factorial & 0.087 & 0.114 \\
9 & -2 & 0 & 0 & Axial & 0.048 & 0.040 \\
10 & +2 & 0 & 0 & Axial & 0.022 & 0.022 \\
11 & 0 & -2 & 0 & Axial & 0.021 & 0.041 \\
12 & 0 & +2 & 0 & Axial & 0.001 & -0.027 \\
13 & 0 & 0 & -2 & Axial & 0.010 & 0.029 \\
14 & 0 & 0 & +2 & Axial & 0.187 & 0.161 \\
15 & 0 & 0 & 0 & Centre & 0.384 & 0.359 \\
16 & 0 & 0 & 0 & Centre & 0.366 & 0.359 \\
17 & 0 & 0 & 0 & Centre & 0.348 & 0.359 \\
18 & 0 & 0 & 0 & Centre & 0.346 & 0.359 \\
\hline
\end{tabular}

$X_{1}=\beta$-glucan's oat, $X_{2}=Y$ east extract, $X_{3}=$ Inoculum, $Y=\beta$-glucanase specific activity $\left(\mathrm{U} \mathrm{mg}^{-1}\right)$

where $\mathrm{Y}$ was the predicted response ( $\beta$-glucanase specific activity), $\beta_{0}$ was the coefficient of interception, $\beta_{i}$ was the coefficient of linear effects, $\beta_{i j}$ was the coefficient of the interaction effects, and $\beta_{i i}$ was the coefficient of the quadratic effects. $X_{i}, X_{i}, X_{(n)}$ were independent variables. Statistical software Design Expert version 9.03.1 (StatEase Inc., Minneapolis, USA) was used to computational design. The accuracy of the model was tested by analysis of variance ANOVA (Table 4). The optimum level for the three independent variables were determined from the second order polynomial equation analysis and 3-D plot of the response surface. An empirically experiments of optimum level for variables recommended by software were needed to validate the accuracy.

\section{Precipitation of $\beta$-glucanase}

Precipitation was performed to obtain optimum fractionation with various saturation percentage of 
Table 4: Analysis of variance of the experimental results of the central composited design

\begin{tabular}{lccccc}
\hline Source & $\begin{array}{c}\text { Sum of } \\
\text { squares }\end{array}$ & df & $\begin{array}{c}\text { Mean } \\
\text { square }\end{array}$ & F value & $\begin{array}{c}\text { P value } \\
\text { Prob }>F\end{array}$ \\
\hline Model & 0.29 & 9 & 0.032 & 45.09 & $<0.0001^{b}$ \\
$X_{1}$-Oat & $3.422 \mathrm{E}-004$ & 1 & $3.422 \mathrm{E}-004$ & 0.49 & 0.5051 \\
$\mathrm{X}_{2}$-Yeast extract & $4.692 \mathrm{E}-003$ & 1 & $4.692 \mathrm{E}-003$ & 6.68 & $0.0324^{\mathrm{a}}$ \\
$\mathrm{X}_{3}$-Inoculum & 0.017 & 1 & 0.017 & 24.79 & $0.0011^{\mathrm{a}}$ \\
$\mathrm{X}_{1} \mathrm{X}_{2}$ & $4.050 \mathrm{E}-005$ & 1 & $4.050 \mathrm{E}-005$ & 0.058 & 0.8163 \\
$\mathrm{X}_{1} \mathrm{X}_{3}$ & $7.605 \mathrm{E}-004$ & 1 & $7.605 \mathrm{E}-004$ & 1.08 & 0.3287 \\
$\mathrm{X}_{2} \mathrm{X}_{3}$ & $6.160 \mathrm{E}-003$ & 1 & $6.160 \mathrm{E}-003$ & 8.77 & $0.0181^{\mathrm{a}}$ \\
$\mathrm{X}_{1}{ }^{2}$ & 0.15 & 1 & 0.15 & 208.61 & $<0.0001^{\mathrm{b}}$ \\
$\mathrm{X}_{2}{ }^{2}$ & 0.17 & 1 & 0.17 & 240.26 & $<0.0001^{\mathrm{b}}$ \\
$\mathrm{X}_{3}^{2}$ & 0.095 & 1 & 0.095 & 135.64 & $<0.0001^{\mathrm{b}}$ \\
Residual & $5.623 \mathrm{E}-003$ & 8 & $7.028 \mathrm{E}-004$ & & \\
Lack of fit & $4.675 \mathrm{E}-003$ & 5 & $9.349 \mathrm{E}-004$ & 2.96 & 0.2005 \\
Pure error & $9.480 \mathrm{E}-004$ & 3 & $3.160 \mathrm{E}-004$ & & \\
Corr total & 0.29 & 17 & & & \\
\hline
\end{tabular}

${ }^{a} p<0.05=$ Significant at $5 \%$ level, ${ }^{b} p<0.0001=$ Significant at $0.1 \%$ level

ammonium sulphate (Scopes, 1994). Precipitation used serial ammonium sulphate concentrations from $0 \%$ to $80 \%$ saturation. The precipitate was stored at $4^{\circ} \mathrm{C}$ for $24 \mathrm{~h}$ and centrifuged at $3985 \mathrm{xg} 4^{\circ} \mathrm{C}$ (centrifuge Hermle with rotor 220.97) for $30 \mathrm{~min}$. The pellet was diluted into $50 \mathrm{mM}$ phosphate buffer $\mathrm{pH} 7$ and it was measured for $\beta$-glucanase specific activity.

\section{In vitro test of fungal pathogens inhibition by $\beta$-glucanase enzyme}

The crude $\beta$-glucanase produced by original and optimized medium, and also the ammonium sulphate fractionation of the $\beta$-glucanase were tested against $C$. affinis and C. gloeosporioides on PDA using agar well diffusion method (Asril, 2014). The well containing $200 \mu \mathrm{L} \beta$-glucanase was placed oppositely at a distance of fungal pathogen at least $3 \mathrm{~cm}$. Inhibition of fungal pathogens by enzyme was observed after 7 days incubation.

\section{RESULTS AND DISCUSSION}

\section{Screening of $\boldsymbol{\beta}$-glucanase produced by bacteria}

The screening of bacterial $\beta$-glucanase showed that there are 3 isolates had glucanolytic activity, as indicated by the formation of a clear zone surroundings around the bacterial colony of SAHA 3.5, SAHA 12.17, and SAHA 32.6, respectively. Isolate SAHA 32.6 showed the highest glucanolytic index (Table 2). Glucanolytic index was calculated from comparison of the differences of clear zone diameter and bacterial colonies with the bacterial colonies diameter. The clear zone formed around the colony showed substrate hydrolyzed into glucose. Congo-red dye will detect nonpolar hydrogen linked $(\beta$-glycosidic) on polysaccharides. The detection due to the strongly hydrophobic interactions of van der walls between dye and polysaccharide which contain nonpolar hydrogen linked (Teather and Wood 1982; Mazeau and Wyszomirski 2012).

A general substrate which is mostly used in the production of $\beta$-glucanase to inhibit the growth of pathogenic fungi is a $\beta-1,3$-glucan or known as laminarin (Callosa) (Bowman and Free, 2006). Several previous studies showed that $\beta$-glucan from a variety of sources had been used as a substrate for the production of $\beta$-glucanase, i.e. the filamentous fungal cell wall extract ( $\beta$-1,3-glucan) (El-Katatny et al., 2000; Bowman and Free, 2006), yeast cell wall extract ( $\beta$-1,3-1.6glucan) (Blättel et al., 2011), and chitin (Leelasuphakul et al., 2006). Suryadi et al. (2013) used oat bran as a substrate in the production of bacterial $\beta$-glucanase which could inhibit the growth of pathogenic fungi Pyricularia oryzae. Beta-glucan derived from cereal grains like oats have $\beta-1,3-$ 1,4-glycosidic linked (Beer et al., 1996) and easily soluble in an alkaline solution.

The inhibition of fungal pathogen growth by bacteria is calculated with the equation $=\left(\mathrm{R}_{1}-\mathrm{R}_{2}\right) \mathrm{R}_{1}^{-1} \times 100 \%$, where $R_{1}$ is length of radial growth towards plate edge and $R_{2}$ is length of radial growth towards bacteria. Isolate SAHA 12.17 could inhibit only the growth of Colletotrichum gloeosporioides, and isolate SAHA 3.5 could inhibit only the growth of Curvularia affinis. This is suspected due to their glucanolytic index is lower than glucanolytic index of isolate SAHA 32.6, so they could not inhibit both of fungal pathogen. Beta-glucanase produced by SAHA 32.6 presumably degrade $\beta$-glucan cell wall of fungal pathogen better than SAHA 12.17 and SAHA 3.5. Isolate SAHA 32.6 was then selected to further works.

\section{Identification of selected bacteria}

Isolate SAHA 32.6 had colony with morphology of irregular shape and spread, grooved edges, and flat elevation. The culture was indicated as Gram positive. Identification of molecular based on $16 \mathrm{~S}$ rRNA sequencing showed that SAHA 32.6 was related to Bacillus subtilis strain SCKB1444 with 99\% similarity (Fig. 1). Bacillus subtilis is known as biological control agent of several fungi which caused disease in widely plants species. B. subtilis produced: (i) lytic enzymes of chitinase, $\beta$-glucanase, protease, lipase, and cellulase which can degrade cell wall of fungal pathogens (Cazorla et al., 2007); (iv) lipopeptide antifungal, i.e. fengcyin, iturin A, and surfactin (Cazorla et al., 2007); (iii) bacillibactin, a compound of chelating iron (Dertz et al., 2006); volatile organic compounds which trigger induced systemic resistance of host plants from fungal pathogens attack (Compant et al., 2005). Isolate SAHA 32.6 was then selected to further works. 


\section{Bacterial growth curve and $\beta$-glucanase production} Supernatant was analyzed for $\beta$-glucanase specific activity every 3 h until 24 h. Beta-glucanase-producing B. subtilis strain SAHA 32.6 was associated with cell growth. This enzyme was produced at the beginning of growth and the highest activity was reached at the end of the logarithmic phase (Fig. 2). According to Stülke et al. (1993), Aono et al. (1995), and Tang et al. (2004) experiments, $\beta$-glucanase was produced when cells enter stationary phase. Glucanase activity increased only when cells stopped growing after either lack of glucose or amino acid starvation (Stulke et al., 1993). Glucose acts as carbon catabolite control which repress expression of $\beta$-glucanase gene when glucose is still available (carbon catabolite repression/CCR) and it will be activated when glucose is exhausted (carbon catabolite activation/CCA) (Fujita, 2009). In this case, carbon source supply only from $\beta$-glucan and no addition glucose to media caused glucanase activity in logarithmic phase. This case also happened in Giese et al. (2011) research, $\beta$-glucanase- producing fungi of Botryosphaeria rhodina was secreted in the stationary phase when the media containing glucose and secreted in the logarithmic phase when the media containing only botryosphaeran ( $\beta$-glucan) as a carbon source. The highest enzyme activity of isolate SAHA 32.6 achieved during the $12 \mathrm{~h}$ of incubation $\left(0.242 \mathrm{U} \mathrm{mg}^{-1}\right)$. This time was used for cultivation process in optimization conditions using RSM.

\section{Optimization using RSM}

Preliminary research on $\beta$-glucanase production using B. subtilis SAHA 32.6 showed that the most important cultural conditions were oat $\beta$-glucan, yeast extract, and inoculum. According to some studies, these three variables have a considerable influence on the $\beta$-glucanase production of Bacillus sp (He et al., 2003; Tang et al., 2004; Khare and Upadhyay, 2011). Cultivation process needed 12 hours of incubation time. The results of CCD experiments along with the observed and predicted response values were presented in the Table 3. Analysis using Design Expert 9.03.1 software suggest the quadratic model equation was fitted predict the optimum $\beta$-glucanase production. The model equation was as followed:

$$
\begin{aligned}
\mathrm{Y}= & 0.35910-0.00463 \mathrm{X}_{1}-0.01713 \mathrm{X}_{2}+0.0330 \mathrm{X}_{3} \\
& -0.00225 \mathrm{X}_{1} \mathrm{X}_{2}+0.00975 \mathrm{X}_{1} \mathrm{X}_{3}-0.027750 \mathrm{X}_{2} \mathrm{X}_{3} \\
& -0.08198 \mathrm{X}_{1}^{2}-0.08798 \mathrm{X}_{2}^{2}-0.06610 \mathrm{X}_{3}^{2}
\end{aligned}
$$

Where $\mathrm{X}_{1}$ was the concentration of oat $\beta$-glucan, $\mathrm{X}_{2}$ was the concentration of yeast extract, $\mathrm{X}_{3}$ was the size of inoculum, and $Y$ was the predicted of $\beta$-glucanase specific activity $\left(\mathrm{U} \mathrm{mg}{ }^{-1}\right)$. Analysis of variance (ANOVA) showed that the model was significant. Zambare (2010) reported that regression model has a very significance if the fisher test showed a very low probability value. 'Lack of Fit P-value' of 0.2005 implied Lack of Fit is not significant relative to pure error and that the model fit.

The linear effects of $\mathrm{X}_{2}$ and $\mathrm{X}_{3}$ were significant $(\mathrm{p}<0.05)$ whereas $X_{1}$ was not significant (Table 4). However the quadratic effects of them showed greater significant because having P-value $<0.0001$. This was indicated that all variable were significantly influenced on the $\beta$-glucanase production. This indicates that the inoculum provides strongly positive influence than oat $\beta$-glucan and yeast extract. This is similar with Aono et al. (1995), De La Cruz et al. (1995), and Tang et al. (2004) experiments that the $\beta$-glucanase production was significantly influenced by concentration of inducer, as well as yeast extract (Khare and Upadhyay, 2011), and inoculum size (He et al., 2003). Especially, the variable of inoculum size showed greater significant results in linear and quadratic effects. Linear effect of inoculum size is the only factor that had a positive value. $\mathrm{X}_{2} \mathrm{X}_{3}$ interaction effect (interaction between

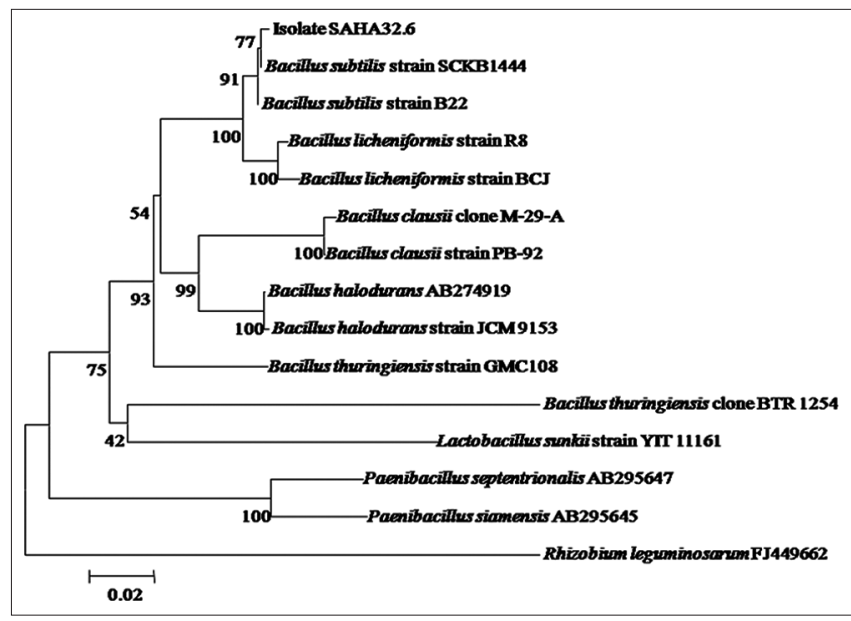

Fig 1. Phylogenetic tree based on Neighbour Joining method with 1000 replication of bootstrap.

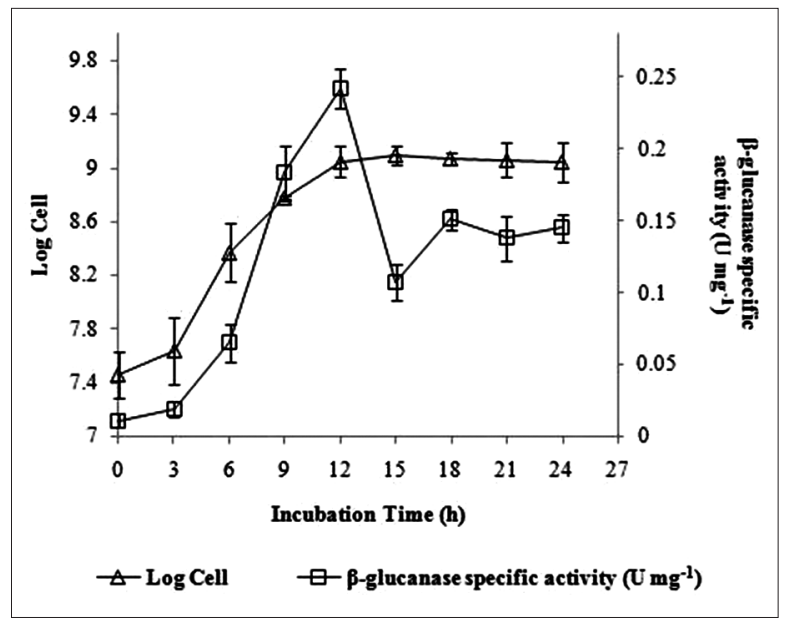

Fig 2. Bacterial growth and $\beta$-glucanase specific activity of the isolate SAHA 32.6 on production media supplemented with $1 \% \beta$-glucan. 


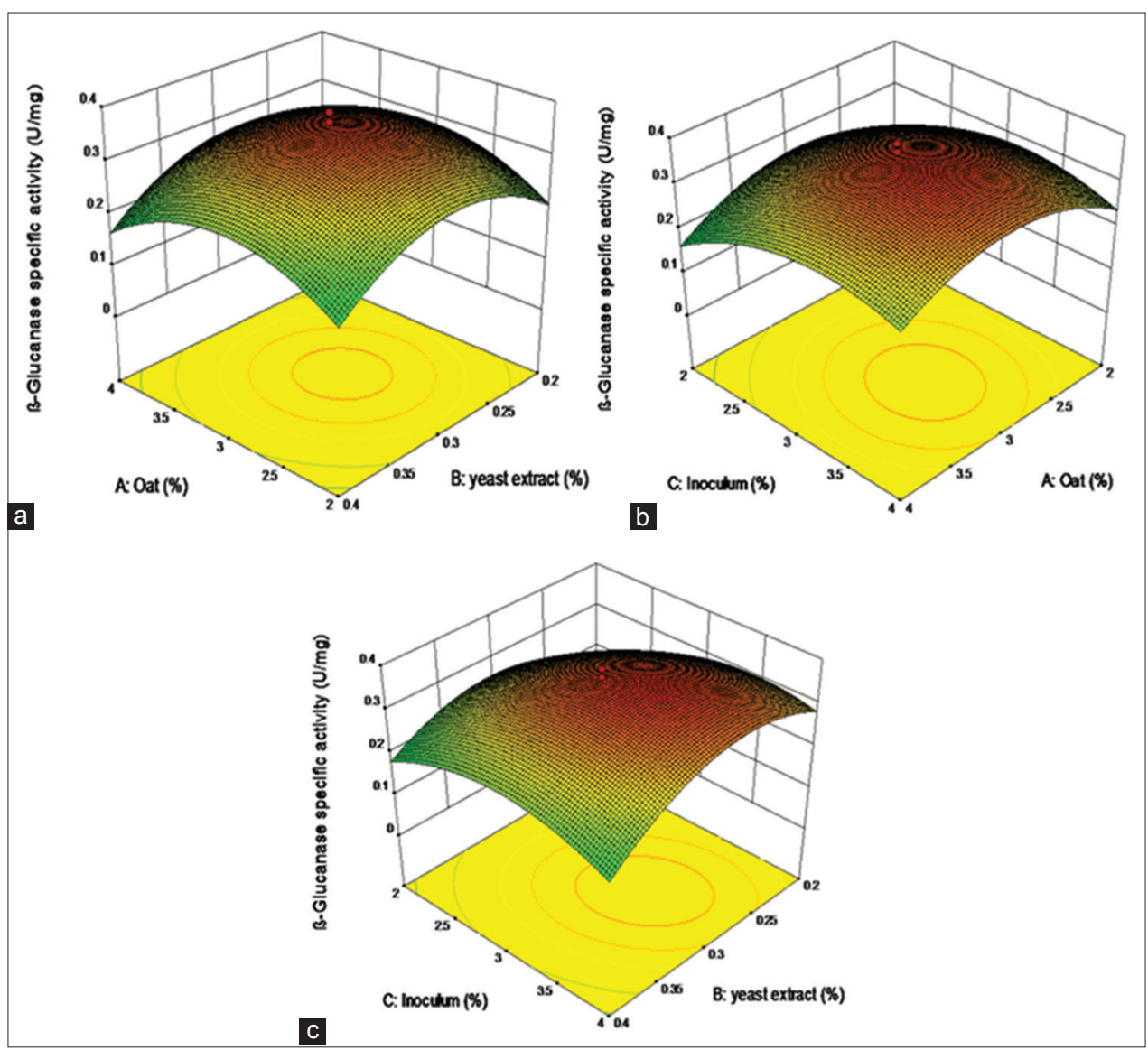

Fig 3.Three-D response surface showed interaction variables on the production of $\beta$-glucanase by B. subtilis SAHA 32.6: (a) Oat $\beta$-glucan and yeast extract with $3 \%$ inoculum, (b) Inoculum and oat $\beta$-glucan with $0.3 \%$ yeast extract, (c) Yeast extract and inoculum with $3 \%$ oat $\beta$-glucan.

yeast extract concentration and inoculum concentration) significantly influenced the activity of the $\beta$-glucanase as the $\mathrm{p}$-value below the level of $\alpha 0.05$, while the $\mathrm{X}_{1} \mathrm{X}_{3}$ interaction effect (interaction between $\beta$-glucan oat and inoculum) and $\mathrm{X}_{1} \mathrm{X}_{2}$ (interaction between $\beta$-glucan oat and yeast extract) had no significant effect.

Quadratic regression coefficient (R-Squared) $\mathrm{R}^{2}=0.9807$ indicates that the model could explain $98,07 \%$ of the variability in response. Adequate presicion used to measure the signal to noise ratio. A ratio greater than 4 is desirable. In this model the adequate precision showed 19.582, which indicated this model can be used to navigate the design space for the response $\mathrm{Y}$. The 'Pred $\mathrm{R}^{2}$ of 0.8590 is in reasonable agreement with the 'Adj $\mathrm{R}^{2}$ ' of 0.9589 for $\mathrm{Y}$ (Adinarayana and Elliaiah, 2002). Thus, the model can be used to determine the optimum conditions of variable of oat $\beta$-glucan concentration, yeast extract concentration, and inoculum size that affected on the $\beta$-glucanase activity.

The 3D-response surface described the effect of multiple variables interaction: oat $\beta$-glucan-yeast extract (Fig. 3a); oat $\beta$-glucan-inoculum (Fig. 3b); and inoculum-yeast extract (Fig. 3c). Beta-glucanase specific activity increased along with the increasing concentration of oat $\beta$-glucan and yeast extract. However, a decrease in $\beta$-glucanase specific activity occurred when increasing the yeast extract concentration too much. Fig. $3 \mathrm{~b}$ and $3 \mathrm{c}$ described that $\beta$-glucanase specific activity reach the maximum value at high inoculum concentration.

The study explained that the inoculum and $\beta$-glucan were more required than yeast extract. Beta-glucan was required in sufficient quantities because at a certain substrate concentration, activity of the enzyme is not increased anymore due to all parts of the enzyme active site has been saturated by substrate (Aono et al., 1995). Yeast extract is a source of nitrogen that supports the growth of bacteria and required in small amounts to trigger the production of $\beta$-glucanase. Limited sources of nitrogen will cause the bacteria could not uptake the nitrogen as a nutrient source, and then the bacteria will produce $\beta$-glucanase to degrade $\beta$-glucan as an alternative source of nutrition (Stülke et al., 1993). In contrast to $\beta$-glucan and yeast extract, $5 \%$ inoculum concentration still showed high $\beta$-glucanase activity. Stanburry et al. (1995) reported that the best inoculum size in the metabolites production was from $3 \%$ to $10 \%$. Hence, the optimum medium for $\beta$-glucanase 
production of B. subtilis SAHA 32.6 were $2.99 \%$ oat $\beta$-glucan, $0.28 \%$ yeast e-xtract, and $3.28 \%$ inoculum with predicted $\beta$-glucanase specific activity of $0.365 \mathrm{U} \mathrm{mg}^{-1}$.

The validation results showed there is no significantly difference between actual value $\left(0.365 \mathrm{U} \mathrm{mg}^{-1}\right)$ and predicted value $\left(0.360 \mathrm{U} \mathrm{mg}^{-1}\right)$. It indicated that RSM model can be used for the $\beta$-glucanase production of B. subtilis SAHA 32.6. Medium optimization able to increase 1.5 fold $\beta$-glucanase spesific activity when compared with nonoptimized medium ( $1 \%$ oat $\beta$-glucan, $0.15 \%$ yeast extract, $1 \%$ inoculum), i.e. from $0.242 \mathrm{U} \mathrm{mg}^{-1}$ to $0.365 \mathrm{U} \mathrm{mg}^{-1}$. He et al (2003) research showed that the optimum conditions in the $\beta$-glucanase produced by B. subtilis were $6.3 \%$ barley $\beta$-glucan, $3.82 \%$ inoculum, and $4.4 \%$ corn flour during the 16 hours of incubation at $210 \mathrm{rpm}$ agitation, temperature $37^{\circ} \mathrm{C}, \mathrm{pH} 7$ with actual $\beta$-glucanase activity of $275.25 \mathrm{U} \mathrm{ml}^{-1}$.

\section{Precipitation of $\beta$-glucanase by $60 \%$ ammoniumsulphate} The crude extract of $\beta$-glucanase produced by optimized medium of isolate SAHA 32.6 which was precipitated by ammonium sulphate at a concentration of $60 \%(\mathrm{w} / \mathrm{v})$ (Fig. 4) was able to increase the purity of $\beta$-glucanase of 1.43 times (Table 5). The $\beta$-glucanase activity of B. subtilis SAHA 32.6 increased 2.13 times, i.e. from $0.240 \mathrm{U} \mathrm{mg}^{-1}$ to $0.515 \mathrm{U} \mathrm{mg}^{-1}$ (Fig. 5). Yang et al. (2008) reported that $\beta$-glucanase from Paecilomyces thermophilla J18 was able to precipitated by the addition of $60 \%$ ammonium sulphate.

\section{In vitro test of fungal pathogens inhibition by bacterial culture and $\beta$-glucanase produced by $B$. subtilis SAHA 32.6}

Beta-glucanase produced by non-optimized and optimized medium, and $60 \%$ sulphate precipitation were tested against $C$. affinis and $C$. gloeosporioides. The results showed that $\beta$-glucanase of non-optimized medium could not inhibit the growth of fungal pathogens, $\beta$-glucanase from optimized medium could inhibit the fungal pathogens, whereas the precipitated $\beta$-glucanase could inhibit these fungals better (Fig. 6). It showed that the magnitude of inhibition of fungal pathogens depend on high enzyme activity. This research also showed that the use of bacteria was much effective in inhibiting fungal pathogen than use of crude enzyme extract. However, the use of $\beta$-glucanase was indicated more effective than use of bacteria only otimization and fractionation.

Beta-glucanase was more effective to inhibit $C$. gloeosporioides than $C$. affinis. It was suspected that the content of $\beta$-glucan in the C.gloeosporioides higher than that of C. affinis. Odabasi et al. (2006) reported that the content of $\beta$-glucan is quite different in each of fungi. However, $\beta$-glucanase were exposed to $C$. affinis will have an impact on the reduction of fungal black pigment (Fig. 6a-e). DHN-melanin pigment is black pigment on mycelia of Curvularia (Rizner et al., 2003). DHN-melanin in the fungal pathogen is not an essential factor in the growth and development of the cell, but can make the fungi survive and competitive under extreme environments. In addition, melanin provides protection against sclerotia and conidia of lysis, turgor pressure for apresoria to penetrate into the host plant leaves, and plays an important role in the process of electron transfer and signal transduction (Beltrán-Garcia et al., 2014). Melanin is localized on the cell walls of pathogenic fungi and crosslinked to polysaccharides (Beltrán-Garcia et al., 2014). Beta-glucan is a kind of polysaccharides in the cell wall of fungi. Thus, it was expected indirectly to degrade DHNmelanin linked to $\beta$-glucan which to reduce mycelial C. affinis pigmentation.

In this study, $\beta$-glucanase specific activity of isolate SAHA 32.6 is not as high as Bacillus on research of Thakaew and Niamsup (2013), which only $0.360 \mathrm{U} \mathrm{mg}^{-1}$ after optimization and $0.515 \mathrm{U} \mathrm{mg}^{-1}$ after precipitation. Thakaew and Niamsup (2013) said $\beta$-glucanase specific activity reached up to $2.3 \mathrm{U} \mathrm{mg}^{-1}$. This is presumably due to the fact that they use different substrates on enzyme production. Thakaew and Niamsup (2013) used mycelia extract of pathogenic fungi as a carbon source. Fungal mycelia is not only composed of glucans and chitin but also galactomannan which were cross-linked to each other (Adam, 2004). In the $\beta$-glucanase production, bacteria have carbon sources not only from glucan but also from chitin and mannan. With the presence of sufficient carbon source, the cell will growing rapidly and producing a high $\beta$-glucanase specific activity. However, although activity of the precipitated enzyme of B. subtilis SAHA 32.6 was low, it could inhibit the growth of fungal pathogens. It also reported by of Suryadi et al. (2013) where the highest activity of $\beta$-glucanase produced by Pseudomonas aeroginosa

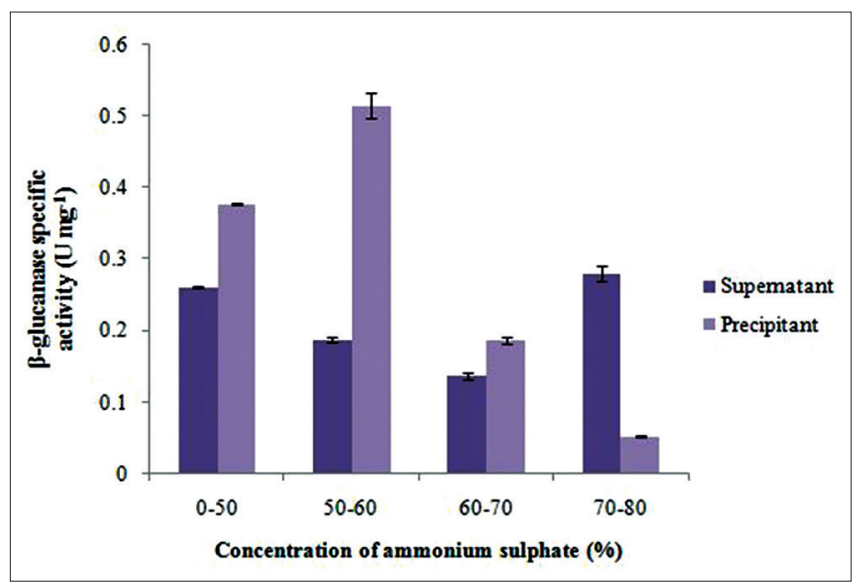

Fig 4. Effect of ammonium sulphate concentration on precipitation of isolate SAHA $32.6 \beta$-glucanase. 
was $0.04 \mathrm{U} \mathrm{mg}^{-1}$ but still inhibit the growth of pathogenic fungi Pyricularia oryzae.

\section{CONCLUSIONS}

Medium optimization using Response Surface Methodology was able to increase the production of $\beta$-glucanase of Bacillus subtilis SAHA 32.6. Medium showed optimum at

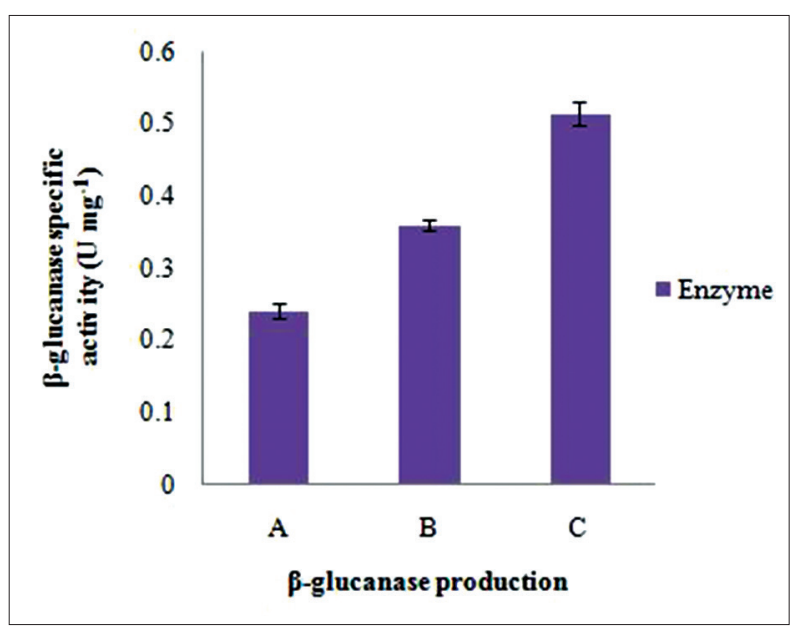

Fig 5. Enhancement of $\beta$-glucanase specific activity of B.subtilis SAHA 32.6 Description: A. Non-optimized medium, B. Optimized Medium by RSM, C. $60 \%$ ammonium sulphate precipitation.
$2.99 \%$ oat $\beta$-glucan, $0.28 \%$ yeast extract, and $3.28 \%$ bacterial inoculum, yielded in predicted $\beta$-glucanase specific activity of $0.365 \mathrm{U} \mathrm{mg}^{-1}$ protein and actual value of $0.360 \mathrm{U} \mathrm{mg}^{-1}$ protein at 12 hours of incubation. Beta-glucanase produced by optimized medium showed increasing of productivity 1.50 times higher than original medium. Precipitation using $60 \%$ ammonium sulphate was able to increase $\beta$-glucanase specific activity to $0.515 \mathrm{U} \mathrm{mg}^{-1}$. Beta-glucanase produced by optimized medium could inhibit fungal Curvularia affinis and Colletotrichum gloeosporioides, but the precipitated $\beta$-glucanase could inhibit these fungal pathogens better than that of original medium and bacterial culture alone.

\section{ACKNOWLEDGEMENTS}

The research was funded by Directorate General of Higher Education (DGHE) Republic of Indonesia and ABS Funds from collaboration CRC IPB - University of Gottingen in 2014 to corresponding author.

\section{Author contributions}

R.T.K.D: Main researcher who collected data, analyzed data, and wrote article. N.R.M: Research supervisor who supported in providing design and references, providing tools and materials; and also corrected the article. M.T.S: Research advisor.
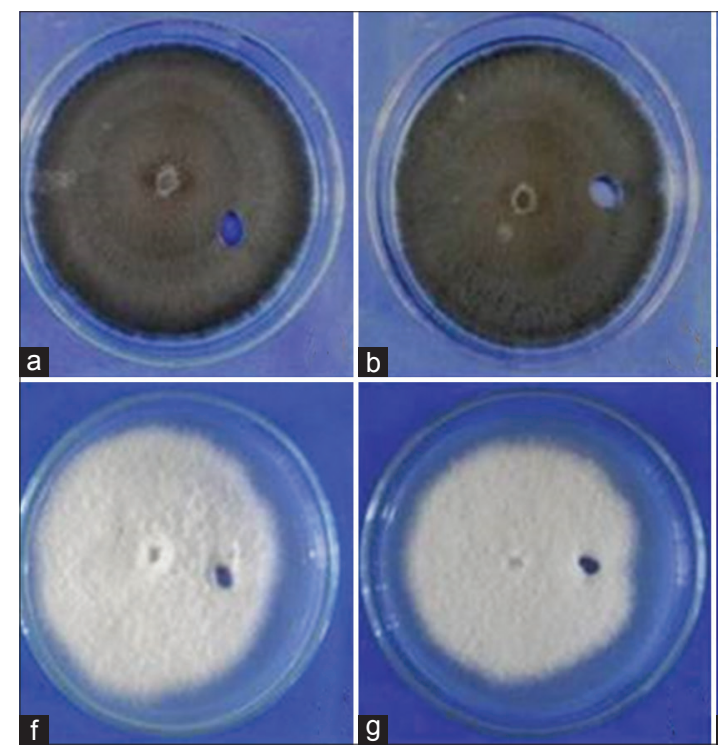
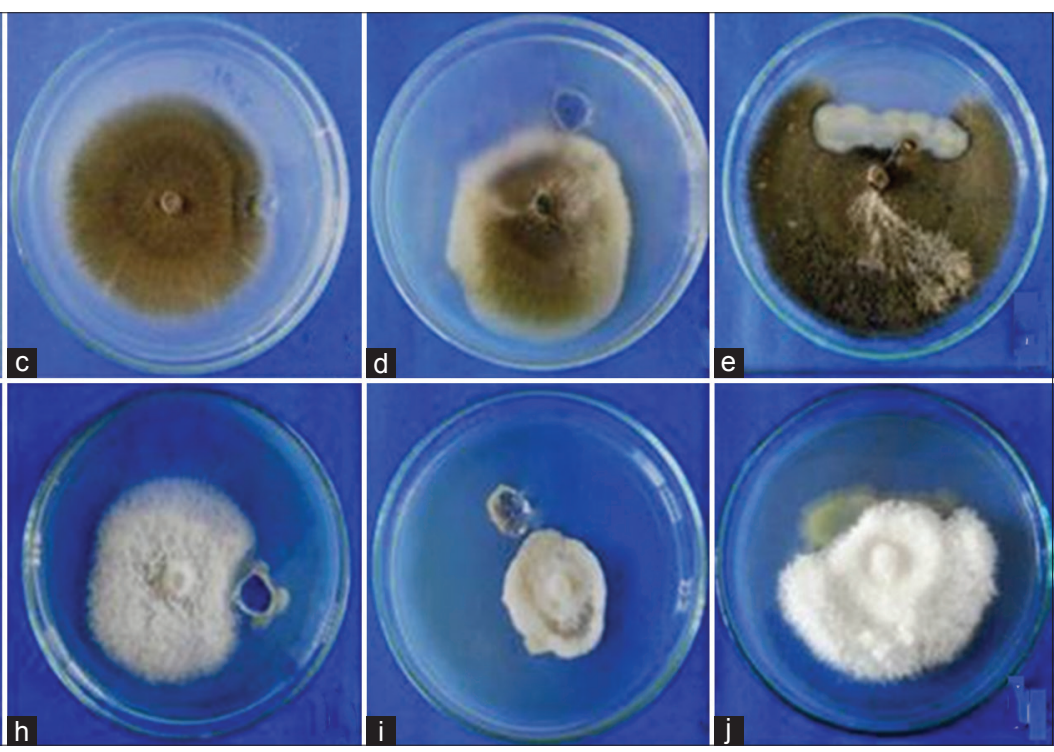

Fig 6. Inhibition of the growth of $C$. affinis (above) and C. gloeosporioides (below) by $\beta$-glucanase of $B$. subtilis SAHA 32.6 on PDA medium (7 days incubation): (a), (f) negative control; (b), (g) $\beta$-glucanase obtained from non-optimized medium; (c), (h) $\beta$-glucanase obtained from optimized medium; (d), (i) $\beta$-glucanase precipitation by $60 \%$ ammonium sulphate; (e), (j) Bacterial culture.

Table 5: Summary of ammonium sulphate precipitation of $\beta$-glucanase produced by B.subtilis SAHA 32.6

\begin{tabular}{|c|c|c|c|c|c|}
\hline Enzyme & Total protein $(\mathrm{mg})$ & Total activity (U) & Specific activity $\left(\mathrm{U} \mathrm{mg}^{-1}\right)$ & Purification (fold) & Yield (\%) \\
\hline Crude extract & 12.48 & 4.48 & 0.359 & 1 & 100 \\
\hline $\begin{array}{l}60 \% \text { ammonium } \\
\text { sulphate precipitation }\end{array}$ & 0.114 & 0.0586 & 0.515 & 1.43 & 1.31 \\
\hline
\end{tabular}




\section{REFERENCES}

Adam, D. J. 2004. Fungal cell wall chitinases and glucanases. Microbiol. 150: 2029-2035.

Adinarayana, K. and P. Ellaiah. 2002. Response surface optimization of the critical medium components for the production of alkaline protease by a newly isolated Bacillus sp. J. Pharm. Pharm. Sci. 5: $272-278$.

Akita, M., K. Kayatama, Y. Hatada, S. Ito and K. Horikoshi. 2005. A novel $\beta$-glucanase gen from Bacillus halodurans C-125. FEMS Microbiol. 248: 9-15.

Aono, R., M. Hammura, M. Yamamoto and T. Asano. 1995. Isolation of extracellular 28- and 42-kilodalton beta-1,3-glucanases and comparison of three beta-1,3-glucanase produced by Bacillus circulans IAM1165. Appl. Environ. Microbiol. 61: 122-129.

Asril, M., N. R. Mubarik and A. T. Wahyudi. 2014. Partial purification of bacterial chitinase as biocontrol of leaf blight disease on oil palm. Res. J. Microbiol. 9: 265-277.

Beer, M. U., E. Arrigoni and R. Amado. 1996. Extraction of oat gum from oat bran: Effects of process on yield, molecular weight distribution, viscosity and $(1,3)(1,4)-\beta$-d-glucan content of the gum. Cereal Chem. 73: 58-62.

Beltrán-Garcia, M. J., F. M. Prado, M. S. Oliveira, A. C. Scalfo, M. H. G. Pessoa, A. Jr. Medeiros, J. F. White and P. di Mascio. 2014. Singlet molecular oxygen generation by light activated DHN-melanin of the fungal pathogen Mycosphaerella fijiensis in black sigatoka diseases of bananas. PLoS Pathog. 9: 1-15.

Blättel, V., M. Larisika, P. Pfeiffer, C. Nowak, A. Eich, J. Eckelt and H. König. 2011. $\beta$-1,3-glucanase from Delftia tsuruhatensis strain MV01 and its application in vinification. Appl. Environ. Microbiol. 77: 983-990.

Bowman, S. M. and S. J. Free. 2006. The structure and synthesis of the fungal cell wall. Bioessays. 28: 799-808.

Bradford, M. M. 1976. A rapid and sensitive method for the quantification on microgram quantities of protein in utilizing the principle of protein dye binding. Anal. Biochem. 72: 248-254.

Cazorla, F. M., D. Romero, A. Perez-Garda, B. J. J. Lugtenberg, A. de Vicente and G. Blomberg. 2007. Isolation and characterization of antagonistic Bacillus subtilis strains from the avocado rhizoplane displaying biocontrol activity. J. Appl. Microbiol. 103: 1950-1959.

Chaari, F., A. Kamoun, F. Bihri, M. Bibech, R. Ellouze-Ghrobel and S. Ellouz-Chaabouni. 2012. Statistical optimization for the production of lichenase by a newly isolated Bacillus licheniformis UEB CF in solid state fermentation using pea pomace as a novel solid support. J. Ind. Crop. Prod. 40: 192-198.

Compant, S., B. Duffy, J. Nowak, C. Clément and E. A. Barka. 2005. Plant growth-promoting bacteria for biocontrol of plant disease: Principles, mechanisms of action, and future prospect. Appl. Environ. Microbiol. 71: 4951-4959.

De la Cruz, J., J. A. Pintor-Toro, T. Benítez, A. Llobellm and L. C. Romero. 1995. A novel endo- $\beta-1,3$-glucanaase, BGN13.1, involved in the mycoparasitism of Trichoderma harzianum. J. Bacteriol. 177: 6937-6945.

Dertz, E. A., J. Xu, A. Stinzi and K. N. Raymond. 2006. Baciilibactinmediated iron transport in Bacillus subtilis. J. Am. Chem. Soc. 128: 22-23.

El-Katatny, M. H., W. Somitsch, K.H. Robra, M. S. El-Katatny and G. M. Gübitz. 2000. Production of chitinase and $\beta-1,3$-glucanase by Trichoderma harzianum for control of the phytopathogenic fungus Sclerotium rolfsii. Food Technol. Biotechnol. 38: 173-180.

Fokkema, N. J. 1973. The role of saprophytic fungi in antagonism against Drechslerand sorokiniana on agar plates and on rye leaves with pollen. Physiol. Plant Pathol. 3: 195-205.

Fridlender, M., J. Inbar and I. Chet. 1993. Biological control of soilborne plant pathogens by a $\beta-1,3$ glucanase-producing Pseudomonas cepacia. Soil Biol. Biochem. 25: 1211-1221.

Fujita, Y. 2009. Carbon catabolite control of the metabolic network in Bacillus subtilis. Biosci. Biotechnol. Biochem. 73: 245-259.

Gautam, A. K. 2014. Colletotrichum gloeosporioides: Biology, pathogenicity and management in India. J. Plant Physiol. Pathol. 2: 1-11.

Giese, E. C., R. F. H. Dekker, L. S. Scarminio, A. M. Barbosa and R. Silva. 2011. Comparison of $\beta-1,3$-glucanase production by Botryosphaeria rhodina MAMB-05 and Trichoderma harzianum Rifai and its optimization using a statistical mixture-design. Biochem. Eng. J. 53: 239-243.

He, Q. G., X. J. Tang, M. Ali and Q. H. Chen. 2003. Optimization of cultural conditions for thermostable $\beta-1,3-1,4$-glucanase production by Bacillus subtilis ZJF-1A5. J. Zhejiang Univ. Sci. 4: 719-726.

Jabasingh, S. A. and C. V. Nachiyar. 2012. Optimization of cellulase synthesis by RSM and evaluation of ethanol production from enzymatically hydrolyzed sugarcanase bagasse using Saccharomyces cerevisiae. J. Sci. Ind. Res. 71: 353-359.

Kahar, U. M., M. Salleh and K. M. Goh. 2014. Medium optimization for pullulanase production from Anocy bacillus species using experimental design. Indian J. Biotechnol. 13: 89-97.

Khare, A. and R.S. Upadhyay. 2011. Influence of some culural factors on production of cellulase and $\beta-1,3-$ glucanase by the mutant strains of Trichoderma viride 1433. J. Agric. Technol. 7: 403-412.

Kittimorakul, J., C. Pornsuriya, A. Sunpapao and V. Petcharat. 2013. Survey and incidence of leaf blight and leaf spot diseases of oil palm seedlings in Southern Thailand. Plant Pathol. J. 12: 149-153.

Leelasuphakul, W., P. Sivanunsakul and S. Phongpaichit. 2006. Purification, characterization and synergistic activity of $\beta-1,3-$ glucanase and antibiotic extract from an antagonistic Bacillus subtilis NSRS 89-24 against rice blast an sheath blight. Enzyme Microb. Technol. 38: 990-997.

Lorraque, M., R. Barriot, A. Barre, P. Rouge, B. Dumas and E. Gaulin. 2012. The unique architecture and function of celluloseinteracting protein in oomycetes revealed by genomic and structural analyses. BMC Genomics. 13: 1-5.

Manjula, K. and A. R. Podile. 2005. Production of fungal cell wall degrading enzymes by a biocontrol strain of Bacillus subtilis AF1. Indian J. Exp. Biol. 43: 892-896.

Marchesi, J. R., T. Sato, A. J. Weightman, T. A. Martin, J. C. Fry, S. J. Hiom and W. G. Wade. 1998. Design and evaluation of useful bacterium-spesific PCR primers that amplify genes coding for bacterial 16s RNA. Appl. Environ. Microbiol. 64: 795-799.

Mazeau, K. and M. Wyszomirski. 2012. Modelling of congo redadsorption on the hydrophobic surface of cellulose using molecular dynamics. Cellulose. 19: 1495-1506.

Miller, G. L. 1959. Use of dinitrosalicylic acid reagent for determination of reducing sugar. Anal. Chem. 31: 426-428.

Myers, R. H. and D. C. Montgomery. 2002. Response Surface Methodology: Process and Products Optimization Designed Experiments, $2^{\text {nd }}$ ed. Wiley, New York, US.

Narasimhan, A., D. Bist, S. Suresh and S. Shivakumar. 2013. Optimization of mycolytic enzymes (chitinase, $\beta-1,3-$ glucanase and cellulose) production by Bacillus subtilis, a potential biocontrol agent using one-factor approach. J. Sci. Ind. Res. 72: 172-178. 
Odabasi, Z., V. L. Paetznick, J. R. Rodriguez, E. Chen, M. R. McGinnis and L. Ostrosk-Zeichner. 2006. Differences in beta-glucan levels in culture supernatants of a variety of fungi. Med. Mycol. 44: 267-272.

Pang, Z., K. Otaka, Y. Suzuki, K. Goto and M. Ohnishi. 2004. Purification and characterization of an endo-1,3,- $\beta$-glucanase from Arthrobacter sp. J. Biol. Macromol. 4: 57-66.

Patel, S., D. Kothari and A. Goyal. 2011. Enhancement of dextransucrase activity of Pediococcus pentosaceus mutant SPAm 1 by response surface methodology. Indian J. Biotechnol. 10: 346-351.

Pitson, S. M., R. J. Seviour and B. M. McDougall. 1993. Noncellulolytic fungal $\beta$-glucanases: Their physiology and regulation. Enzyme Microb. Technol. 5: 178-192.

Rižner, T. L. and M. H. Wheeler 2003. Melanin biosynthesis in the fungus Curvularia lunata (teleomorph: Cochliobolus lunatus). Can. J. Microbiol. 49: 110-119.

Saharan, B. S. and V. Nehra. 2011. Plant growth promoting rhizobacteria. Life Sci. Med. Res. 21: 1-30.

Scopes, R. K. 1994. Protein Purification, Principles and Practice, $3^{\text {th }}$ ed. Springer-Verlag, New York, US.

Solehudin, D., I. Suswanto and Supriyanto. 2012. Status penyakit bercak coklat pada pembibitan kelapa sawt di Kabupaten Sanggau. J. Perkebunan Lahan Trop. 2: 1-6.

Stanbury, P. F., A. Whitaker and S. J. Hall. 1995. Principles of Fermentation Technology, $2^{\text {nd }}$ ed. Butterworth-Heinemann, Oxford, UK.
Stülke, J., R. Hanschke and M. Hecker. 1993. Temporal activation of $\beta$-glucanase synthesis in Bacillus subtilis is mediated by the GTP pool. J. Gen. Microbiol. 139: 2041-2045.

Suryadi, Y., D. N. Susilowati, T. S. Kadir, Z. R. Zaffan, N. Hikmawati and N. R. Mubarik. 2013. Bioformulation of antagonistic bacterial consortium for controlling blast, sheath blight, and bacterial blight disease on rice. Asian J. Plant Pathol. 7: 92-203.

Suwandi., S. Akino and N. Kondo. 2012. Common spear rot of oil palm in Indonesia. Plant Dis. 96: 537-543.

Tang, X. J., G. Q. He, Q. H. Chen, X. Y. Zhang and M. Ali. 2004. Medium optimization for the production of thermal stable $\beta$-glucanase by Bacillus subtilis ZJF-1A5 using response surface methodology. Biores. Technol. 93: 175-181.

Teather, R. M. and P. J. Wood. 1982. Use of congo red-polysacharide interaction in enumeration and characterization of cellulolytic bacteria from bovine Rumen. Appl. Environ. Microbiol. 43: 777-780.

Thakaew, R. and H. Niamsup. 2013. Inhibitory activity of Bacillus subtilis BCC 6327 metabolites against growth of a flatoxigenic fungi isolated from Bird Chili Powder. Int. J. Biosci. Biochem. Bioinform. 3: 27-32.

Yang, S., Y. Qiaojuan, Z. Jiang, G. Fan and L. Wang. 2008. Biochemical characterization of a novel thermostable $\beta-1,3-1,4-$ glucanase (lichenase) from Paecilomyces thermphila. J. Agric. Food Chem. 56: 5435-5351.

Zambare, V. 2010. Optimization of nutritional factors for extracellular protease production from Bacillus $s p$. using response surface methodology. Int. J. BioEng. Technol. 1: 43-47. 